\title{
EFISIENSI EKONOMI SEBAGAI REMEDY HUKUM
}

\author{
Fajar Sugianto \\ Dosen Fakultas Hukum Universitas 17 Agustus 1945 (Untag) Surabaya dan \\ sekaligus sebagai Advokat pada PERADI \\ Korespondensi: fajar.sugianto@yandex.com
}

\begin{abstract}
Abstrak
Hukum dan Ekonomi merupakan salah satu disiplin dalam ilmu hukum yang menawarkan pengutamaan efisiensi ekonomi sebagai kaidah hukum dalam mengarahkan praktik hukum. Dengan melakukan konseptualisasi lebih lanjut, efisiensi ekonomi juga membantu dalam menilai dan melakukan penilaian terhadap hukum. Salah satu bentuk efisiensi ekonomi dalam tulisan ini adalah pendekatan ekonomis terhadap hukum dalam merumuskan keuntungan yang dihasilkan hukum. Dalam hal ini efisiensi ekonomi mengubah hukum sebagai insentif dalam mengubah perilaku manusia seperti halnya mempertahankan perilaku yang sudah sejalan dengan tujuan-tujuan hukum. Hukum seyogianya menentukan upaya perbaikan melalui penghukuman dan penghargaan sebagai insentif untuk mengungkap aspek-aspek tertentu atau krusial dari ilmu hukum.
\end{abstract}

Kata-kata Kunci: Efisiensi Ekonomi; Upaya Perbaikan.

\begin{abstract}
Law and Economics is one of the disciplines in the jurisprudence that offers the primacy of economic efficiency as the rule of law in directing the practice of law. With further conceptualization, economic efficiency is also useful in judging and assessing the law. One relevant form of economic efficiency discussed in this paper is the economic approach to law in formulating the expected profit of the law. In this case, economic efficiency transforms law into an incentive to change human behaviors as well as to maintain certain behaviors that are already in line with the objectives of the law. Laws should determine remedies by way of punishment and rewards as an incentive to reveal certain crucial aspects of jurisprudence.
\end{abstract}

Key Words: Economic Efficiency; Remedies; Law and Economics. 


\section{PENDAHULUAN}

Tidak jauh berbeda dengan perjalanan panjang semua ilmu dan pengetahuan, Hukum dan Ekonomi (Law and Economics) atau juga umumnya disebut Economic Analysis of Law pada awalnya tidak dikenal. Walaupun butir-butir pemikiran seputar Hukum dan Ekonomi sudah ada di dalam ajaran inti jurisprudence, disiplin ilmu ini tidak dikembangkan. Terutama wujudnya sebagai produk peleburan cakrawala keilmuan antara ilmu hukum dan ilmu ekonomi, Hukum dan Ekonomi tidak dikategorikan sebagai bagian disiplin ilmu hukum sehingga tidak memiliki pengakuan akademik, bahkan tidak banyak yang mengenali keberadaan disiplin ilmu ini.

Salah satu faktor tersendatnya perkembangan Hukum dan Ekonomi terletak pada saat perkembangan jurisprudence yang pada saat itu masih berkutat seputar inti-inti ajaran kepastian hukum (legal certainty atau varitas) dan keadilan (justice atau iustitia). Hingga sekarang pun, evolusi hukum dan ilmu hukum pembelajarannya terkesan masih di seputar kedua inti ajaran tersebut.

Diakui oleh banyak pakar bahwa Hukum dan Ekonomi dimulai dari ajaran Bentham $(1789,1827,1830)$ yang menawarkan jalan tengah antara kepastian dan keadilan dengan mengemukakan inti ajaran kemanfaatan, yang kemudian dikenal dengan istilah utilitarian. Tulisantulisan Bentham mengupas secara sistematis dalam meneliti bagaimana manusia akan berperilaku dalam menghadapi hukum, sekaligus mengevaluasi efeknya secara kolektif dan hubungan sebab-akibatnya dalam konteks kesejahteraan sosial (social welfare). Hukum dalam hal ini dikategorikan sebagai insentif untuk merangsang/ memotivasi perubahan perilaku manusia terhadap hukum, bukan semata-mata sebagai perintah, larangan, dan sebagainya itu selayaknya diajarkan oleh ilmu hukum pada umumnya.

Karya-karya momental ini tidak dilihat dan tidak dikembangkan hingga tahun 1960 sampai awal 1970-an, ketika kebutuhan pengkajian hukum melalui bantuan ilmu ekonomi dimotori kembali oleh beberapa pakar hukum melalui karya-karyanya antara lain: Coase (1960) tentang eksternalitas dan tanggung jawab hukum, Becker (1968) tentang kejahatan dan penegakkan hukum, dan Posner (1972) tentang Economic Analysis of Law. Semenjak itu, kebutuhan dan perkembangan analisisanalisis Hukum dan Ekonomi tumbuh pesat, bahkan dewasa ini mulai mendapatkan pengakuan akademik.

Tidak sebatas pengakuan akademik sebagai salah satu disiplin ilmu di dalam Ilmu Hukum saja, namun pembelajaran disiplin ini sudah menjadi mata pelajaran pokok ilmu hukum mulai dari tataran Strata 1 hingga Strata 3 bahkan di beberapa perguruan terkemuka telah menjadi program studi tersendiri. Hal ini dapat dilihat dari beberapa perguruan tinggi di Amerika Serikat seperti Harvard University (Harvard Law School), 
University of Chicago Law School. Di Eropa antara lain: Leiden University, University of Copenhagen, University of Siena, Central European University di Budapest, Utrecht University, dan lainnya. Di Asia misalnya: National University of Singapore. Di Oseania pada University of New South Wales.

Dewasa ini, pengembangan tentang Hukum dan Ekonomi dapat dilihat dari muculnya karya-karya indah tentang Hukum dan Ekonomi yang dipelopori kembali oleh beberapa pakar seperti: Robert Cooter dan Thomas Ulen, Mitchell Polinsky, Richard Posner, Thomas Miceli, Steven Shavell, dan lain-lain. ${ }^{1}$ Seiring dengan pertumbuhan disiplin ini, teori-teori hukum telah mengasimilasi banyak konsep-konsep ekonomi, seperti incentive effects, opportunity costs, risk aversion, transaction costs, asymetric information, open-access resources, median rule, regulatory capture, dan lain sebagainya. Banyak pakar ekonomi menyadari pentingnya keberadaan hukum untuk mengatur hal-hal penting seperti pengaturan hukum properti dan hukum kontrak di dalam pertumbuhan ekonomi. Kesadaran ini membuat keberadaan dan peran hukum menjadi penting dalam mengatur mekanisme perekonomian.

Sebaliknya, ilmu ekonomi melahirkan konsep-konsep ilmu hukum, seperti litigation costs, property rules, liability rules, reliance damages, monetary and non-monetary sanctions, insidertrading, internalized values, third-party enforcers dan sebagainya. ${ }^{2}$ Sinergitas keilmuan ini secara luas menunjukkan bagaimana ilmu ekonomi mampu menguji kemampuan hukum, demikian pula sebaliknya, sehingga perkembangannya membawa kedua disiplin ilmu tersebut menjadi lebih dekat, bahkan membentuk suatu disiplin ilmu yang interdependen.

Hukum dan Ekonomi menawarkan beberapa konsep sebagai model yang menjadi pendekatan ekonomi kepada hukum (economic approach to law), dalam hal ini untuk mencermati praktik hukum. Walaupun pada hakikatnya Hukum dan Ekonomi memiliki inti pendirian teori-teori keilmuan tentang perilaku (scientific theories of behavior), pendekatan ekonomi kepada hukum dalam tulisan ini fokus kepada fungsi hukum sebagai suatu enterprise yang mampu menjadi insentif. Insenitf berarti pendorong untuk mengarahkan serta mempertahankan tindakan atau perilaku tertentu (altering behavior). Kata enterprise memiliki keleluasan konteks, dalam hal ini dapat berarti suatu sistem, wadah, skema, pengaturan, misi, usaha, dan lain sebagainya.

$1 \quad$ Telah tersedia pula bahan sekunder seperti kamus tentang Hukum dan Ekonomi (The New Palgrave Dictionary of Economics and the Law (1998) dan ensiklopedia Law and Economics. Jurnal-jurnal seperti Journal of Legal Studies, the Journal of Law and Economics, the Journal of Law, Economics, and Organization, dan the International Review of Law and Economics. Bahkan wadah organisasi profesional seperti the American Law and Economics Association telah terbentuk.

2 Fajar Sugianto, Economic Analysis of Law, Seri I: Pengantar Seri Analisis Ke-ekonomian tentang Hukum (Prenada Media Kencana 2013) 19. 
Dari beberapa konsep yang ada, penekanan akan dilakukan kepada keunggulan konsep efisiensi (primacy of economic efficiency) sebagai salah satu cara pandang ekonomi terhadap hukum yang dapat membantu hukum tidak saja menjadi alat untuk mencapai tujuan hukum-hanya berperan sebagai penyedia keadilan atau menegakkan kepastian hukum, namun sekali lagi sebagai insentif dalam mencapai sasaran dan cita-cita hukum.

\section{PEMBAHASAN}

\section{Beberapa Konsep Fundamental Ilmu Ekonomi}

Konsep-konsep fundamental ini seperti prinsip-prinsip hukum, saling terkait dan melengkapi antara satu dengan yang lain. Seperti prinsip hukum juga, konsep-konsep ekonomi (misalnya efisiensi) tidak berdiri sendiri, sehingga perlu melihat konsep-konsep lainnya yang menjadi satu kesatuan penjabaran dan pengertian. Itulah sebabnya uraian singkat terhadap konsep-konsep fundamental ilmu ekonomi berikut ini tidak disusun sendiri-sendiri, karena semuanya saling menjelaskan dan melengkapi, dan yang terpenting adalah men-derivasi konsep-konsep berikutnya.

Konsep rasionalitas merupakan kerangka pemikiran utama dalam memahami perilaku manusia. Ilmu ekonomi beranggapan bahwa semua manusia memiliki rasionalitas (kecuali anak-anak dan mereka yang terbelakang). Walaupun kenyataannya tidak semua rasionalitas pada setiap individu adalah sama, rasionalitas manusia dalam ilmu ekonomi lebih ditekankan kepada persamaan keinginan manusia. Keinginan ini ialah usaha manusia untuk memenuhi kebutuhannya dan mencapai kepuasan sehingga manusia dikatakan sebagai rational maximizer.

Usaha manusia ini melibatkan pilihan. Mereka mampu mengkalkulasi (sesuai dengan tingkat rasionalitasnya itu) pilihan-pilihan yang tersedia untuk kemudian mengambil keputusan yang dirasa terbaik bagi mereka. Kemampuan memilih seperti ini juga dikatakan rasionalitas manusia. Oleh karena manusia memiliki rasionalitas semacam ini, dan rasionalitas identik dengan peningkatan, maka manusia sebagai pelaku ekonom dapat melakukan penarafan terhadap alternatif-alternatif yang tersedia pula. Dari alternatifalternatif ini, manusia dapat memilih pilihan terbaik berikutnya (next-best alternative choice) berdasarkan rasionalitasnya masing-masing. Cara lain yang umum digunakan untuk memahami konsepsi perilaku rasionalitas manusia adalah dengan mengakui bahwa manusia akan memilih alternatif yang terbaik untuk memenuhi kebutuhan mereka.

Kebanyakan orang menginginkan lebih dari sumber daya yang tersedia dan yang memungkin untuk mereka miliki. Ini adalah konsep kelangkaan: terbatasnya sumber daya yang tersedia karena digunakan manusia untuk memenuhi kebutuhannya. Kelangkaan memaksa manusia untuk membuat pilihan yang paling berharga. Hal ini menekankan bahwa jika orang tidak 
dapat memilih pilihan yang benar, maka mereka akan memilih alternatif terbaik berikutnya. Definisi suatu pilihan yang "benar" bervariasi dari satu orang ke orang lain, sekali lagi berdasarkan rasionalitas dan kebutuhan mereka.

Dari sudut pandang ekonomi, suatu pilihan dapat dikatakan benar apabila tepat sasaran dalam kegiatan ekonomi yang berakhir dengan hasil yang paling berharga, dalam hal ini memuaskan. ${ }^{3}$

Manusia sebagai rational maximizer cenderung mencapai tujuannya dengan cara yang paling efisien. Beberapa pakar Hukum dan Ekonomi memiliki perbedaan penjabaran terhadap konsep efisiensi yang dibangun berdasarkan definisi yang berbeda-beda. Demi kemudahan konseptualisasi, penulis mengadopsi teori Pareto efisiensi yang umumnya menyangkut kepuasan dan preferensi individu sebagai salah satu konsep efisiensi yang banyak diterapkan dalam Hukum dan Ekonomi, dan Kaldor Hicks efficiency yang juga sering digunakan. Garner membagi efisiensi Pareto menjadi dua jenis, pertama adalah Pareto superiority as an economic situation in which an exchange can be made that benefits someone and injures no one (garis bawah oleh penulis). Pada saat keadaan ekonomi ini tidak dapat terjadi, maka dapat dikatakan efisiensi
Pareto optimality, yaitu an economic situation in which no person can be made better off without making someone else worse off (garis bawah oleh penulis). ${ }^{4}$ Sementara Kaldor-Hicks efficiency concept: a situation in which all possible wealth-maximizing changes have occurred (garis bawah oleh penulis). Wealth maximazation didefinisikan sebagai: a situation resulting from a change in the allocation of resources if the change benefits the winner. ${ }^{5}$ Konsepkonsep efisiensi semacam ini mengarah kepada unsur keadilan dalam hukum.

Terdapat hubungan yang sangat penting antara efisiensi dan utilitas. Bagi kebanyakan pelaku ekonom, utilitas merefleksikan kemanfaatan dan faedah terhadap barang ekonomi. Jika seseorang percaya bahwa tindakannya itu secara sukses efisien, maka pada saat yang sama ia menyimpulkan hasilnya adalah memuaskan. Hasil yang memuaskan ini menandakan efektivitas di balik tindakannya. Hasil yang memuaskan seperti ini juga mencerminkan kepuasan manusia atas terpenuhinya keinginan yang juga memiliki sifat moneter dan atau nonmoneter. Kepuasan manusia dapat dikategorikan sebagai keuntungan ekonomi yang bersifat moneter dan atau non-moneter. ${ }^{6}$

3 The reflextive rationality adalah kemunculan jenis rasionalitas yang menggantikan dua rasional sebelumnya. Dikutip dari Dian Ediana Rae, Transaksi Derivatif dan Masalah Regulasi Ekonomi di Indonesia (Elex Media Komputindo 2008) 263.

Bryan A. Garner, Black Law Dictionary (Thompson West Group 2004) 1147.

Ibid. 1624.

Keuntungan ekonomi (economic profit) tidak sama dengan keuntungan dalam tata buku (accounting profit). Perbedaan dasarnya terletak pada, keuntungan ekonomi bersifat moneter dan atau non-moneter, sementara keuntungan secara tata buku (accounting) dipersamakan dengan uang. Accounting Profits = Total Revenue - Explicit Cost, sementara Economic Profits $=$ Total Revenue - (Explicit+Implicit Cost). Dominick Salvatore dan Eugene Diulio, Principles of Economics (Mc.Graw Hill 2003) 128-130. 
Konsep utilitas di dalam Hukum dan Ekonomi digunakan dalam arti yang cukup berbeda, khususnya pengertiannya dalam ilmu ekonomi dan ajaran utilitarian. Bagi kebanyakan ekonom, utilitas pada umumnya digunakan untuk membedakan biaya tidak pasti dari sesuatu yang pasti. Utilitas juga biasanya disebut sebagai utilitas yang diharapkan (expected utility) yang menghasilkan analisa risiko, sementara utilitas dalam arti yang digunakan oleh filsuf utilitarian-isme adalah kebahagiaan.

Dalam Hukum dan Ekonomi, utilitas di dalam penjabaran Analisis Keekonomian tentang Hukum secara sempit diartikan sebagai daya guna atau fungsi untuk mencari kegunaan atau manfaat dari barang ekonomi yang menghasilkan atau memberikan keuntungan, bahkan secara luas dapat diartikan kesejahteraan. Keanekaragaman definisi dari berbagai perspektif ilmu memiliki elemen yang sama, yaitu sebagai usaha manusia meningkatkan keuntungan demi kesejateraan yang memuaskan dirinya sendiri.

Diperjelas sekali lagi bahwa arti kata keuntungan memiliki keleluasan konteks, yaitu secara moneter dan atau non-moneter. Utilitas menjadi salah satu pertimbangan ekonomi sebagai dasar pengambilan keputusan oleh manusia yang pada hakikat-nya ingin mendapatkan manfaat atau keuntungan, sesuai dengan pengharapannya. Keputusan yang diambil ini dikatakan rasional, karena manusia dapat membedakan secara jelas antara untung-rugi yang pasti dan yang tidak pasti. Sesuatu yang tidak pasti ini merupakan risiko yang menjadi pertimbangan ekonomi juga.

Untuk mengambil keputusan, hadir teori permainan, yang pada dasarnya adalah studi tentang bagaimana orang berperilaku dalam situasi di mana tindakannya itu dapat mem-pengaruhi reaksi orang lain. Situasi ini selayaknya seperti sebuah permainan, permainan yang memerlukan strategi. Teori permainan ini memiliki aplikasi yang jauh lebih luas, beberapa ahli ekonomi mengatakannya menjadi teori koordinasi. Wessels menjelaskan bahwa teori permainan memperpanjang alat analisis ekonomi pada setiap situasi di mana manusia harus mengkoordinasikan tindakan mereka dengan satu sama lain, baik dalam keluarga, di tempat kerja, dalam kelompok sosial, bahkan dalam hubungan suatu negara dengan negaranegara lain. Ia menambahkan dua kerangka pemikiran penting di dalam teori permaianan. Pertama, penekanan terhadap rasionalitas manusia dalam menyusun strateginya yang terdiri atas pilihan-pilihan, sehingga rasionalitas semacam ini dikategorikan sebagai preferensi manusia yang tertata dengan baik. Kedua, ia menghubungkan kausalitas dari strategi-strategi tersebut, sehingga menimbulkan reaksi, dampak, dan akibat kepada orang lain. ${ }^{7}$ 
Pada titik ini, segala pertimbangan biaya-biaya dicermati manusia. Biaya seperti ini dikenal dengan istilah biaya transaksi atau transaction cost. Umumnya biaya transaksi adalah segala biaya yang dikeluarkan karena adanya faktor eksternalitas dalam berinteraksi atau bertindak, dalam hal ini untuk mengambil keputusan. Kata biaya memiliki keleluasan arti sebagai: pengeluaran moneter dan atau moneter, dampak, risiko, kekurangan, kelemahan. ${ }^{8}$ Keputusan yang diambil dengan segala pertimbanganpertimbangan tadi merupakan strategi. Strategi ini harus dominan, berarti strategi yang lebih baik daripada strategi lain terlepas dari apa yang orang lain lakukan di dalam permainan. Ini mendorong dan merangsang keinginan manusia untuk saling bekerja-sama dalam positive-sum game. Teori ini banyak digunakan di dalam Hukum dan Ekonomi untuk mengukur daya tahan pengaturan peraturan hukum (regulating regulations), misalnya dalam mengkonsepkan sanksi hukuman pidana sebagai efek jera.

\section{Penilaian Efisiensi Ekonomi sebagai Norma Hukum}

Ilmu hukum kaya akan teori, ajaran, konsep, norma, dan prinsip. Tidak sedikit para cendekiawan hukum terus menambah kekayaan ilmu hukum, misalnya terhadap norma hukum. Meskipun kaya, tidak ada satupun yang mutlak benar dan serba guna atau serba bisa. Kegunaan dan validitas suatu norma, teori, ajaran, prinsip dan sebagainya itu bergantung pada berhasilnya mereka menjelaskan dan memprediksi serangkaian fenomena yang menjadi bahan penjelasan dan prediksi. Oleh karena itu, secara terus menerus dan tiada hentinya harus dikaji ulang melalui pengamatan. Hasilnya, sering kali dimodifikasi atau diperbaharui dan kadang-kadang dibuang, bahkan didekonstruksi yang kemudian dikonstruksikan kembali. Proses pengkajian dan pembaharuan menjadi inti pengevaluasian pengembangan hakikat hukum sebagai ilmu.

Berangkat dari tolak ukur ini, sangat perlu dilakukan penilaian terhadap keunggulan efisiensi ekonomi terhadap hukum. Sebagaimana yang telah diungkap sebelumnya tentang hukum sebagai insentif, pendekatan ekonomi kepada hukum melihat pentingnya hukum tidak dalam sanksi dan penghukumannya saja namun bagaimana hukum juga dapat memberikan imbalan dan penghargaan bagi mereka yang patuh/taat hukum. Penghukuman dan imbalan seperti ini umum dikenal dengan sebutan punishment and reward. Imbalan dalam bentuk penghargaan merupakan salah satu remedy hukum untuk menjadi insentif, yaitu sebagai pendorong merubah perilaku manusia dan memotivasi ketaatan hukum untuk meningkatkan efisiensi ekonomi. 
Di Indonesia, pelaksanaan penghukuman dan imbalan terkesan tidak berimbang, lebih banyak terfokus kepada penghukuman atau penjatuhan sanksi-sanksi hukum. Jika diukur melalui elemen ketaatan hukum, maka dapat dikatakan bahwa jumlah subjek hukum yang taat masih jauh lebih kecil dibandingkan dengan mereka yang tidak patuh/taat hukum. Sehingga tidak mengherankan dalam banyak hal, penerapan hukum masih terkonsentrasi pada penegakkan sanksi hukum ketimbang pemberian imbalan. Seberapa seringkah kita mendapatkan imbalan dan penghargaan terhadap tindakan taat atau tertib hukum?

Untuk mempermudah dan memperluas penilaian ini, dihadirkan dua contoh yang sekiranya dapat mempermudah pencermatan kegiatan hukum dalam hal penghukuman dan imbalan sebagai remedy hukum melalui efisiensi ekonomi.

Contoh pertama di Jepang, penghukuman dan pengimbalan dapat dilihat dari praktik hukum dalam berlalu lintas. Tentunya untuk mengendarai kendaran bermotor diperlukan Surat Ijin Mengemudi (SIM), selain sebagai ijin mengemudi SIM juga menjadi semacam kartu identitas diri. Setelah melalui berbagai macam ujian, calon pengendara yang telah dewasa menurut hukum dan yang dinyatakan lulus mendapatkan SIM pertama yang diterbitkan oleh unten menkyo shikenjou (semacam Ditlantas di sana namun lebih khusus menangani SIM) dengan ciri warna hijau. Sebagai pemula, SIM berwarna (garis) hijau ini diberikan masa berlaku hanya tiga tahun. Setelah tiga tahun, SIM tersebut ditingkatkan menjadi warna biru yang menandakan si pemegang SIM bukan lagi pemula. Masa berlaku yang diberikan adalah sama, tiga tahun. Hanya saja semenjak "di upgrade", segala track record pemegang SIM berwarna biru ini akan terdata dan tersimpan dengan baik untuk mengetahui sejauh mana ia bermasalah dengan hukum dalam berlalu lintas. Segala bentuk pelanggaran, termasuk juga kecelakaan lalu lintas, tilang, parkir ilegal akan mendeterminasi apakah ia mampu diberi penghargaan berupa peningkatan ke SIM berwarna emas ketika SIM berwarna biru habis masa berlakunya. SIM berwarna emas ini selain memiliki prestise tersendiri, juga menunjukan tingkat kedewasaan seseorang dalam berlalu lintas, dalam hal ini sebagai seseorang yang taat atau tertib hukum. Selain itu, SIM berwarna emas ini didukung dengan kemudahankemudahan, seperti masa berlaku menjadi setiap lima tahun, dan perpanjangan dapat dilakukan melalui keisatsusho (semacam polsek setempat). Sebaliknya, jika si pemegang SIM melakukan banyak pelanggaran, maka SIM yang awalnya berwarna biru tadi tidak akan ditingkatkan menjadi warna emas. Demikian pula dengan pemegang SIM berwarna emas jika melakukan banyak pelanggaran maka akan diturunkan kembali menjadi warna biru. Hal-hal ini tercatat dan dapat dideteksi hanya dengan melihat SIM itu sendiri dari periodik waktu. Dalam keadaan 
tertentu, SIM dapat dicabut apabila si pemegang SIM dinilai terlalu bermasalah melalui pelanggaran-pelanggaran tertentu atau pengulangan berkali-kali. Sekali dicabut tidak semudah memohon dari awal ketika pertama kali memohon SIM. Pengevaluasian yang sangat ketat, keharusan untuk mengikuti pendidikan formal (walaupun hanya untuk berlalu lintas), bahkan pada taraf tertentu permohonan kembali SIM tidak diperbolehkan.

Contoh ini mengilustrasi-kan bagaimana hukum dapat menjadi insentif melalui penghukuman dan pemberian imbalan yang setimpal kepada masyarakat-nya sebagai wajud kepastian hukum dan keadilan. Imbalan hukum membantu tujuan hukum untuk merubah perilaku manusia dalam mencapai efisiensi ekonomi. Jika tidak, akan timbul anggapan-anggapan bahwa taat hukum dan acuh hukum adalah sama sepanjang tidak melanggarnya.

Pengimbalan dan penghargaan hukum dirasa tidak berlebihan, karena jika hukum adalah milik masyarakat maka masyarakat harus memiliki kebanggaan sebagai kelompok sosial yang taat/tertib hukum sehingga merefleksikan kedewasaan dalam berhukum. Selain membantu mengarahkan masyarakat ke cita-cita hukum, sudah saatnya hukum dapat memberikan semacam prestise sosial yang menunjukan "peradaban hukum" tersendiri. Dengan tumbuhnya prestise sosial seperti ini secara bersamaan akan menumbuhkan rasa malu kepada kelompok lainnya yang belum dewasa dalam berhukum sekaligus memotivasi dan mengundang mereka untuk ikut masuk di dalam prestise sosial yang dibanggakan secara sosial. Hal seperti inilah yang disebut dengan hukum sebagai economic goods.

Terhadap pola ini, jika dirasa efisiensi ekonomi dapat membawa ke arah perbaikan hukum maka tidak ada salahnya ditransplantasikan ke dalam hukum kita. Terutama untuk negara hukum, penilaian dan perlindungan kepada masyarakat taat/tertib hukum menjadi konsekuensi perwujudan equality before the law. Tidak berlebihan kiranya sebagai Rechtsstaat tidak mewujudkan equality before the law sebatas pada persamaan kedudukan di muka hukum, tetapi ikut mewujudkan equal protection. Transplantasi hukum dalam hal penghukuman dan pengimbalan dapat dimaknai sebagai bentuk penyaluran di mana hukum kita harus menangkap keuntungan yang mampu dihasilkan oleh hukum.

Contoh kedua melihat praktik diskresi dalam berlalu lintas di Indonesia yang umum ditemukan. Pada saat jam padat intensitas para pengguna jalan menjadi meningkat. Dengan pertimbangan efisiensi demi kemudahan dan kelancaran secara kolektif, polisi lalu lintas sering melakukan tindakan diskresi yang secara positif dilarang hukum. Tidak jarang ditemukan, alat pemberi isyarat lalu lintas diabaikan dan para pengguna jalan, khususnya kendaraan bermotor mengikuti aba-aba atau petunjuk dari polisi lalu lintas. Marka jalan tidak difungsikan 
sebagaimana mestinya, tempat penyeberangan jalan digunakan untuk menampung desakan pengemudi bermotor roda dua, trotoar yang merupakan fasilitas pendukung pejalan kaki dalam banyak kesempatan dialihkan kepada kendaraan pengguna jalan, dan lain sebagainya.

Dari sudut pandang ekonomi, diskresi semacam ini adalah efisien dan bentuknya mengarah kepada reward. Dapat dibayangkan bagaimana jadinya jika para aparat penegak hukum di jalan menerapkan hukum secara legalistik. Tidak hanya kekacauan dan inefisiensi, namun dampaknya tidak mendekati sasaran hukum itu sendiri, dalam hal ini salah satunya adalah ketertiban dan kelancaran berlalu lintas. Di sisi lain, Hukum dan Ekonomi mencermati bagaimana efek diskresi ini bila tidak didukung dengan elemen-elemen lainnya, misalnya tingkat kesadaran (hukum) manusia sebagai pengguna jalan dan konsistensi pelaksanaannya. Hasilnya, diskresi yang pada awalnya bermanfaat secara kolektif perlahanlahan dan sedikit demi sedikit menjelma menjadi semacam praktik kebiasaan. Kebiasaan menikmati reward yang diberikan aparat penegak hukum (dalam hal ini polisi lalu lintas beserta prenata lainnya) kepada pengguna jalan kendaraan bermotor dalam mengabaikan fungsi marka jalan misalnya dipraktik-kan di luar jam padat. Hasil hukum yang dihasilkan tanpa mempertimbangkan efek jangka panjang dapat dikatakan tidak efisien. Efek-efek hukum dan pemberlakuan hukum semacam inilah menjadi salah satu inti fokus pencermatan Hukum dan Ekonomi.

Dari kedua contoh beserta pencermatan di atas, langkah selanjutnya adalah melakukan penilaian (evaluation) terhadap efisiensi ekonomi sebagai norma hukum. Secara luas, efisiensi merupakan model ideal yang dapat memandu kegiatan hukum, bahkan pada titik-titik tertentu efisiensi ekonomi mampu menyatukan disparitas hasil hukum. Walaupun manusia memiliki rasionalitas, pertimbangan ekonomi, dan alasan ekonomis yang berbeda-beda sehingga efisiensi yang dilahirkan identik dengan preferensinya masing-masing, manusia secara luas memiliki persamaan, yaitu kebutuhan akan efisiensi. Persamaan ini dapat menjadi faktor yang menentukan ukuran (criterion) perilaku manusia. Jika hukum secara luas sungguhsungguh sebagai enterprise yang mengatur perilaku manusia untuk tunduk dan patuh terhadap tata kelola peraturan, maka salah satu parameter keberhasilan dan kesuksesan hukum ialah masyarakat memiliki pengetahuan tentang hukum dan harus memiliki keyakinan kepadanya. Demikian pula sebaliknya, hukum memiliki pengetahuan tentang manusia sebagai subjek hukum. Bagaimana mungkin hukum dapat melakukan segala fungsi dan tugasnya untuk mencapai tujuan hukum jika masih tetap acuh terhadap fakta ekonomi bahwa masih banyak kaum lemah diatur oleh enterprise (dalam hal ini hukum sebagai sistem) yang mereka tidak mengerti atau percaya. 
Semakin jelas bahwa efisiensi ekonomi, paling tidak, memberikan gambaran tentang efek hukum kepada perilaku manusia. Sebagai pelaku ekonom, manusia memiliki berbagai macam kebutuhan yang ingin dipenuhi. Dalam banyak hal, hukum telah menjadi kebutuhan manusia, terutama bagi kita yang hidup di dalam negara hukum. Kebutuhan manusia akan hukum baik sebagai alat maupun komoditas dengan berbagai macam tujuannya itu tidak dapat dipisahkan dengan praktik sosial lainnya. Untuk itu, hukum sine qua non berjalan seiring senada dengan kegiatan sosial lainnya.

Jelas sekali manusia memiliki kebutuhan akan peraturan hukum yang baik. Baik bukan dalam konteks benarsalah, tetapi efisien dan efektif. Efisien dalam hal ini berarti tepat sasaran dan sesuai di dalam praktiknya. Efektif artinya praktik hukum mampu berjalan senada dengan kegiatan sosial manusia lainnya. Dengan hukum seperti ini akan berdampak ke arah perbaikan yang membawa segala keuntungan sebagai akibatnya. Keinginan manusia akan hukum seperti ini menjadi kebutuhan, dan dikatakan langka (scarce).

Dampak dan akibat hukum ke arah perbaikan menjadikan hukum melalui efisiensi ekkonomi menjadi insentif, yaitu mengubah sikap dan perilaku manusia sekaligus mengarahkan dan mempertahankannya. Efek-efek dasar dan dampak hukum terhadap perilaku manusia sebagai aktor yang berkepentingan seperti ini mendudukan efisiensi ekonomi sebagai norma hukum.

\section{PENUTUP}

Keunggulan efisiensi ekonomi (primacy of efficiency) menawarkan salah satu cara mencermati kegiatan hukum melalui dimensi dan cara-cara yang berbeda dengan tidak mengurangi bobot hukum. Efisiensi ekonomi juga membantu efikasi hukum untuk menemukan kemampuan hukum sesuai dengan keinginan dan harapan sebagai enterprise yang mengatur perilaku manusia. Dimensi lain yang coba ditawarkan melalui kehadiran efisiensi ekonomi ialah keberadaannya sebagai suatu pendekatan untuk memahami kompas hukum di tengah-tengah belantara hukum. Seperti yang telah dikemukakan berkali-kali, hukum melalui efisiensi ekonomi mampu menjadi insentif, yaitu mengubah sikap dan perilaku manusia sekaligus mengarahkan dan mempertahankannya sesuai dengan sasaran/cita-cita hukum. Usaha perbaikan (remedy) semacam ini ingin meng-ungkapkan aspek-aspek penting yang definitif sebagai esensi dasar fondasi hukum dan ilmu hukum, dan ini tidak asing dalam jurisprudence.

Dalam konteks keberhasilan hukum, efisiensi ekonomi paling tidak didudukan sebagai norma hukum yang memiliki decesive factor untuk mengevaluasi dan melakukan penilaian terhadap hukum. Bila dianalisis secara ekonomis, hukum dapat diubah menjadi instrumen untuk mencapai tujuan sosial yang penting, sehingga kegiatan hukum mampu berjalan seiring senada dengan praktik-praktik sosial lainnya. 


\section{DAFTAR BACAAN}

Garner, Bryan A., Black Law Dictionary (Thompson West Group 2004).

Rae, Dian Ediana, Transaksi Derivatif dan Masalah Regulasi Ekonomi di Indonesia (Elex Media Komputindo 2008).

Salvatore, Dominick, dan Eugene Diulio, Principles of Economics (Mc. Graw Hill 2003).

Sugianto, Fajar, Economic Analysis of Law, Seri I: Pengantar Seri Analisis Ke-ekonomian tentang Hukum (Prenada Media Kencana 2013). , Economic Approach to Law, Seri II: Pendekatan Ekonomi Kepada Hukum, Seri Analisis Ke-ekonomian tentang Hukum (Prenada Media Kencana 2013).

Wessels, Walter J., Economics ( Barron's Educational Series 2006). 